\title{
Insecticidal activity of some botanical extracts against legume flower thrips and legume pod borer on cowpea Vigna unguiculata L. Walp
}

Juliana Amaka Ugwu

\begin{abstract}
Background: Insect pests infestation is one the major constraints to cowpea production in many Sub-Saharan Africa including Nigeria. Control of these pests by farmers has been vastly by use of chemical pesticide which possesses lots of threats to human health and environments. This study is aimed at evaluating insecticidal efficacy of petroleum ether seed extracts of four plants (Azadirachta indica, A. Juss, Piper guineense Schum and Thonn, Annona muricata L., and Jatropha curcas L.) against legume flower thrips, Megalurothrips sjostedti Tryb., and legume pod borer, Maruca vitrata Fab. on cowpea as alternative eco-friendly options for the control of the cowpea field pests.

Methods: The extracts were applied at the rate of $10 \mathrm{ml} / \mathrm{l}$ of water at 1 week intervals for 6 weeks starting from 7 weeks after sowing (WAS) and replicate three times. The extracts were compared with lambdacyhalothrin at $5 \mathrm{ml} / \mathrm{l}$ of water as a standard check and untreated control.

Results: The results showed that all the treatments significantly $(p<0.05)$ reduced the population of legume bud thrips and legume pod borer compared to control. A. muricata followed by Piper guineense significantly $(p<0.01)$ reduced the population of legume flower thrips and legume pod borer as well as pod damage compared to other extracts. The percentage reduction of $M$. sjostedti and $M$. vitrata population by the extracts ranged from $52.07-69.28 \%$ and $57.78-$ 78.52\% respectively compared to control. Cowpea yield was significantly $(p<0.05)$ higher in plots treated with $A$. muricata and Piper guinense compared to other extracts. The efficacies of A. muricata and $P$. guineese were significantly $(p$ $<0.05$ ) higher than lambdacyhalothrin for the control of legume flower thrips and legume pod borer of cowpea.

Conclusion: Petroleum ether seed extracts of A. muricata and $P$. guineense were very potent against legume flower thrips and pod borer, and thus they can be effectively used by smallholder farmers for the management of cowpea post flowering pests. These plant products are readily available, environment friendly, and are suitable for low-income agriculture practiced in developing countries.
\end{abstract}

Keywords: Cowpea, Biopesticides, Maruca vitrata, Megalurothrips sjostedti, Pest management

Correspondence: dr.amaka2013@gmail.com

Department of Forest Technology, Federal College of Forestry, Forestry

Research Institute of Nigeria, P.M.B.5087, Jericho Hills, Ibadan, Oyo State,

Nigeria

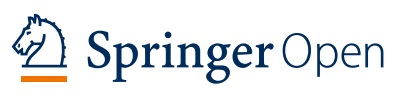

(c) The Author(s). 2020 Open Access This article is licensed under a Creative Commons Attribution 4.0 International License, which permits use, sharing, adaptation, distribution and reproduction in any medium or format, as long as you give appropriate credit to the original author(s) and the source, provide a link to the Creative Commons licence, and indicate if changes were made. The images or other third party material in this article are included in the article's Creative Commons licence, unless indicated otherwise in a credit line to the material. If material is not included in the article's Creative Commons licence and your intended use is not permitted by statutory regulation or exceeds the permitted use, you will need to obtain permission directly from the copyright holder. To view a copy of this licence, visit http://creativecommons.org/licenses/by/4.0/. 


\section{Background}

Cowpea (Vigna unguiculata L. Walp) is one of the major grain legumes that are widely cultivated in semiarid areas of subtropics and tropics for human and animal consumption (Singh \& van Emden, 1979). Cowpea is identified as vegetable meat due to high amount of protein in the grain with better biological value on dry weight basis (Owolabi, Ndidi, James, \& Amune, 2012).

World production of cowpea was estimated to be 2.27 million tons of which Nigeria produces about 850,000 tons (Adaji, Olufala, \& Aliyu, 2007; FAO, 2002). Cowpea production in Sub-Saharan Africa accounts for more than 94\% of the world production (FAOSTAT, 2011). About 90\% of the world cowpea is produced in West Africa with 4,525, 891 tons of dried grains harvested within an annual area up to 12 million hectares (FAOSTAT, 2014). Cowpea is highly significance to the livelihoods of millions of relatively poor people in less developed and developing countries of the tropics (FAO, 2002).

Insect pests contribute up to $70 \%$ grain yield reduction in cowpea (Alghali, 1992; Edema, R.\& Adipala, E., 1996), the most vital field insects among them being Aphis craccivora Koch., Megalurothrips sjostedti Trybom, Maruca vitrata Fabricius, and a complex of pod-sucking bugs especially Clavigralla tomentoscollis Stat. and Riptortus dentipes Fab. (Karungi, Adipala, Nampala, Ogenga-Latigo, \& Kyamanywa, 2000b). According to Malgwi and Onu (2004), the most important and prevalent field insect pests of cowpea in Nigeria are aphids (Aphis craccivora Koch.), legume flower thrips (Megalurothrips sjostedti Trybom), legume pod borer (Maruca vitrata Fab), spiny brown bug (Clavigralla tomentosicollis Stal.), flower beetle (Mylabris species), leaf-footed plant bug (Leptoglossus australis F.), and foliage beetle (Ootheca mutabilis Sahib).

Maruca vitrata (Lepidoptera, Pyralidae) and Megalurothrips sjostedti (Thysanoptera, Thripidae) are among the most damaging pests of legumes (Tanzubil, Tanzubil, 1991, Tanzubil, 2000).

Infestation rate of Maruca vitrata can get to $80 \%$, and they causes seed damage of up to $50 \%$ if no control measures are administered (Dreyer, Baumgartner, \& Tamo, 1994). M. vitrata and M. sjostedti are significant reproductive pests of cowpea that causes flower abortions and pod setting problems (Tamo, Bottenberg, \& Arodekoum, D.\& Adeoti R., 1997).

The feeding activities of $M$. sjostedti cause necrosis that subsequently leads to shading of cowpea flowers and buds. The cowpea yield losses due to $M$. sjostedti infestation are estimated at between 20-70\% (Edema, R.\& Adipala, E., 1996; Rusoke \& Rubaihayo, 1994; Singh \& Allen, 1980).

Management of insect pests of cowpea is mainly by used chemical insecticides for a very long period of which it has been reported to be very effective by several authors (Jackai, Singh, \& Raheja, A.K.\& Wiedijk, K., 1985). Control of legume pod borer damage is mainly by timely application insecticides, but their effectiveness is hindered by the tight larval webbing that reduces pesticide exposure (Grigolli, Lourenção, \& Avila, 2015). In Nigeria, two applications of lambdacyhalothrin or cypermethrin in combination with dimethoate were reported to be very cost effective for controlling legume pod borer and improving cowpea yield (Amatobi, 1995). Similarly, control of legume flower thrips is mainly by use of chemical insecticides like deltamethrin, malathion, monocrophos, pirimiphos-methyl cypermethrin, dimethoate, and lambdacyhalothrin which mostly reduces infestation and distinctly increase crop yields (Ekesi, Maniania, Onu, \& Löhr, 1998).

However, these chemical insecticides have several detrimental effects to non-target organisms, human health, and the environment ( Soomro, Seehar, Bhangar, \& Channa, 2008). These detrimental effects of chemical pesticides include pesticide residues in the agricultural products, increase of human and livestock poisoning incidents, pesticide resistance of pests, reduction of natural enemy, and disruption of ecological balance.

Mindfulness about the food safety and consequences of the toxic effects of synthetic pesticides in food production have increased the demand for organically produced food, which demands evaluating the concert of biopesticides as safer alternatives to synthetic insecticides (Akbar, Haq, Parveen, Yasmin, \& Sayeed, 2010). Plant extracts present a vast practically untapped reservoir of chemical compounds with many potential uses.

Many plant parts have been screened for their insecticidal and antimicrobial properties (Anyaele, Amusan, Okorie, \& Oke, 2002; Musa, Dike, Amatobi, \& Onu, 2007). The idea of replacing synthetic insecticides with biopesticides is now a collective acceptable and realistic approach in pest management worldwide (Logan, Cowie, \& Wood, 1990). Several plants have been found effective for control of crop pests in various trials worldwide (Saxena, 1989; Schmuttere, 1990), and most them were found effective on stored pests (Ivbijaro, 1983; Oparaeke, Dike, \& Onu, 1998; Sowunmi \& Akinnusi, 1983; Ugwu, 2016; Ugwu, Omoloye, \& Obasaju, 2012) and in some field insect pests (Oparaeke, 2006). The use of botanicals pesticides for pest management is being advocated due to several advantages they have over chemical pesticides. These include the following: they possesses less pollution to the environment; have many insecticidal properties with special modes of action which makes it difficult for the pests to develop pesticide resistance; have low toxicity to human, livestock, and natural enemies; and have relatively lowcost production and use.

Thus, this study investigated the efficacy of extracts from four plant seeds in Nigeria against of cowpea flowers thrips and legume pod borer on cowpea under rain fed conditions. 


\section{Materials and methods}

\section{Experimental site}

The study was carried out at the experimental farm of Federal College of Forestry, Jericho, Ibadan, Oyo State, during the 2017 planting season. Ibadan is located within latitude $7^{\circ}$ and $9^{\circ} \mathrm{N}$ longitude $3^{\circ}$ and $58^{\circ} \mathrm{E}$ of Greenwich Meridian Time (GMT) with annual rainfall of about 1300 to $1500 \mathrm{~mm}$ and average relative humidity of about 80 to $85 \%$ (FRIN, 2014).

\section{Collection of the plant materials for extraction}

Plant seeds of Azadirachta indica, Annona muricata, and Jatropha curcas were collected from the Forestry Research Institute of Nigeria, Jericho-Ibadan, while Piper guineense seed was purchased from a local market in Ibadan. The samples were air-dried on side benches in the laboratory for 2 weeks and pulverized with a high-speed mill for subsequent use for the extraction. The pulverized plant seeds were weighed out in $100 \mathrm{~g}$ each, and Soxhlet extracted separately using petroleum ether for minimum of $8 \mathrm{~h}$ according to the methods by (Ofuya et al. 1992).

\section{Land preparation and planting/sowing}

The experimental plot measuring $24 \mathrm{~m} \times 12 \mathrm{~m}$ was manually cleared with cutlass and hoe and allowed to stand for 14 days before rigging in $1 \mathrm{~m}$ apart. Poultry manure was applied at rate of $2.5 \mathrm{t} / \mathrm{ha}$ as a basal treatment. Six plots measuring $3 \mathrm{~m} \times 1 \mathrm{~m}$ were marked out in three replicates using randomized block design. Each plot consisting of three ridges of $1 \mathrm{~m} \times 0.5 \mathrm{~m}$ was separated by $1 \mathrm{~m}$ wide border along the ridge. Cowpea variety "Ife brown" collected from Institute of Agricultural Research and Training (IAR\&T) were sown at the spacing of $50 \mathrm{~cm} \times 50 \mathrm{~m}$ at planting rate of 3 seeds per holes. The seedlings were thinned to 2 plants per planting hole 2 to 3 weeks after sowing (WAS).

\section{Application of treatments}

Spraying of extracts and synthetic insecticides commenced 7 weeks after sowing (WAS) at (the initiation of cowpea flowering) weekly interval. The seed extracts were applied at the rate of $10 \mathrm{ml}$ per liter of water using hand sprayer and synthetic insecticide (lambdacyhalothrin) which was used as a standard check was applied at the rate of $2.5 \mathrm{ml} / \mathrm{l}$ of water. A liquid soap $(2.5 \mathrm{ml})$ was added to the mixed extracts to enhance the adhesion of insect before spraying while control plot was left unsprayed. The sprayer was rinsed with profuse amount of water after each treatment application to avoid contamination. Manual weeding was done at five to six WAS to ensure a weed free condition.

\section{Data collection and analysis}

Legume pod borer, $M$. vitrata larvae, was sampled before each spray early in the morning between 7:00 and 8: 00 a.m. by randomly picking of 20 flowers from plants within the three ridges per each plot. The flowers were placed in $25-\mathrm{ml}$ vial containing $30 \%$ ethanol and taken to the laboratory where they were dissected the next day, and the number of $M$. vitrata was counted. Legume flower thrips, M. sjostedti, were also determined by counting the number of adults and larvae in open flowers collected at 7-day intervals before application of the extracts. A total of 20 randomly selected flowers were sampled between 8:00 a.m. and 10:00 a.m. on the two-edge rows of each replicate plot to avoid disturbance of thrips and placed together into a $25-\mathrm{ml}$ plastic vial in 30\% alcohol as described by Oparaeke (2006).

The number of flowers used was a realistic sample size for statistical analysis according to (Tamo et al. 1993). Cowpea pod damages were also assessed at 10 WAS when the pods have attained $75-85 \%$ physiological maturity by observing the constricted pods.

Cowpea pods were harvested dry per plot and weighed. Data collected were subjected to analysis of variance, and significant means were separated using Duncan multiple range test (DMRT).

\section{Results}

Effect of treatments on the population of legume flower thrips

Extracts from the different plant seeds tested excreted different level of efficacy on legume flower thrips. Annona muricata seed extracts were the most effective in reducing the population of legume flower thrips with mean value of 10.90/20 flowers in 1 year of investigation (Fig. 1).

A. muricata significantly $(p<0.01)$ reduced the thrips infestation more than other treatments. This was followed by $P$. guineense with mean value of $14.30 / 20$ flowers. There was no significant difference between $A$. muricata and $P$. guineense in reducing the population of legume flower thrips. A. muricata and P. guineense significantly reduced higher population of flower thrips on cowpea than lambdacyhalothrin while the efficacy of $A$. indica and $J$. curcas was not significantly different $(p>$ 0.05 ) from lambdacyhalothrin in reducing the infestation of flower thrips on cowpea. All the extracts significantly $(p<0.01)$ reduced the cowpea flower thrips infestation compared with the untreated control.

\section{Effect of treatments on the population of legume pod borer on cowpea}

The insecticidal efficacy of the tested seed extracts against cowpea pod borer followed similar trend with that of legume flower thrips (Fig. 2). A. muricata was the most effective in reducing the population of legume 


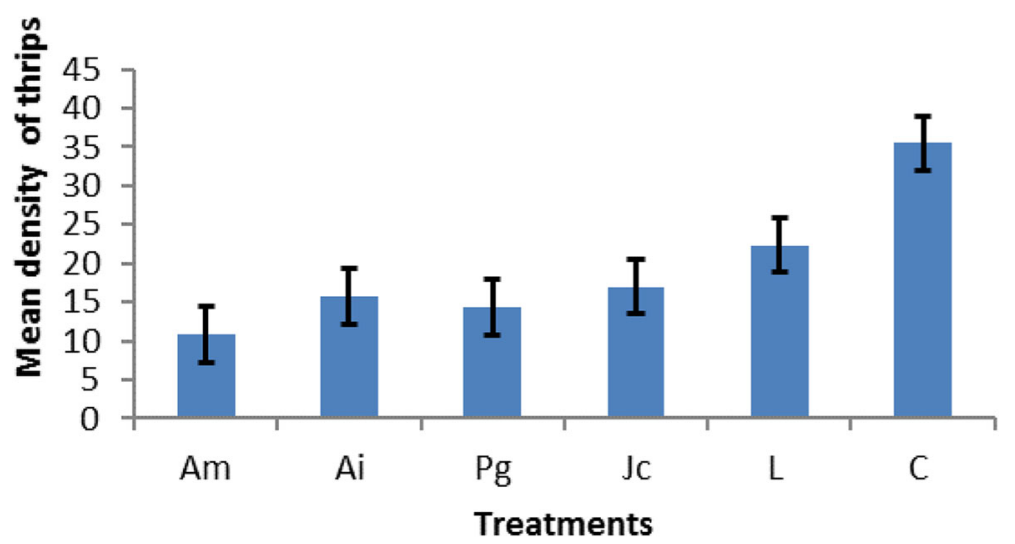

Fig. 1 Effect of treatments on the population of legume flower thrips. Mean values are the number of adult and larvae of flower thrips observed in 20 flowers sampled per plot per week during the flowering period of the cowpea from different plots treated with different botanicals. Am, plot treated with Annona muricata; Ai, plot treated with Azadirachta indica; Pg, plot treated with Piper guineense; Jc, plot treated with Jatropha curcas; L, lambdacyhalothrin; C, control (no treatment)

flower thrips, followed by P. guineense. There were significantly $(p<0.05)$ lower population of legume pod borer in plots treated with $A$. muricata and $P$. guineense extracts than plots treated with other extracts. A. muricata and $P$. guineense extracts significantly $(p<0.01)$ lowered the population of legume pod borer more than other extracts and lambdacyhalothrin. All the extracts significantly $(p<0.05)$ reduced the population of legume pod borer compared with untreated control.

\section{Effect of treatments in reducing legume flower thrips and pod borer population}

The mean population and percentage reduction of legume flower thrips and pod borer is shown in Table 1.
A. muricata reduced infestation of legume pod borer and flower thrips by $69.24 \%$ and $78.52 \%$ respectively when compared to control. All the extracts were more effective than lambdacyhalothrin in reducing pod borer and flower thrips population. The populations of the legume pod borer and legume flower thrips were minimized by the extracts by more than $50 \%$ when compared with control.

\section{Effect of treatments on the number of cowpea pod damage}

The result reveals that extracts evaluated were effective in reducing cowpea pod damage due to insect pests infestation (Fig. 3). Plots sprayed with $A$. muricata recorded lower number of damaged cowpea pods, followed by plots sprayed with $P$. guineense extracts. The efficacy of $A$.

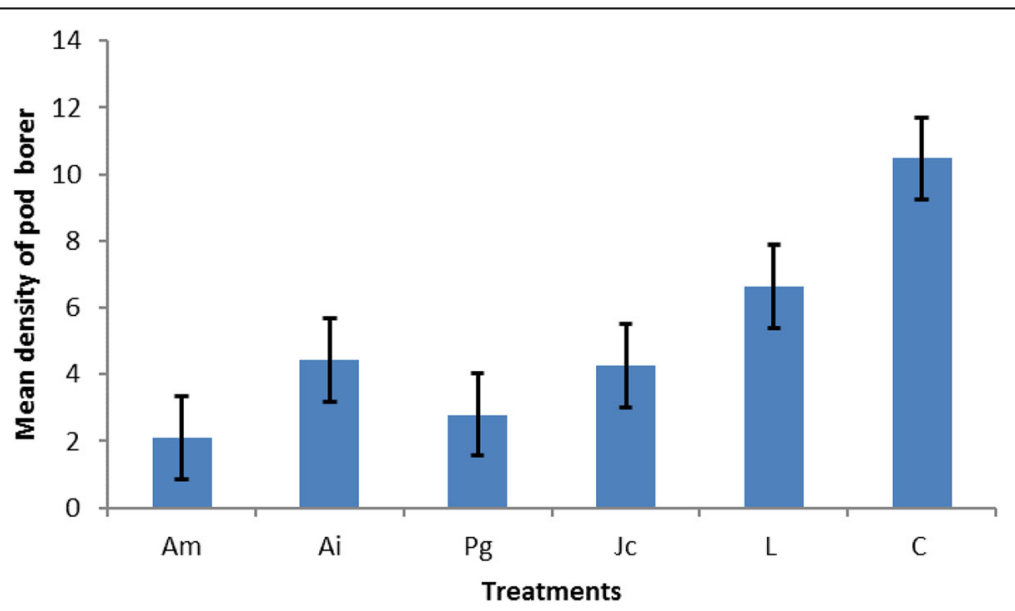

Fig. 2 Effect of treatments on the population of legume pod borer on cowpea. Mean values are the number of legume pod borer larvae observed in 20 flowers sampled per plot per week during the flowering period of the cowpea from different plots treated with different botanicals. Am, plot treated with Annona muricata; Ai, plot treated with Azadirachta indica; Pg, plot treated with Piper guineense; Jc, plot treated with Jatropha curcas; L, lambdacyhalothrin; C, control (no treatment) 
Table 1 Mean population and percentage reduction of legume flower thrips and pod borer

\begin{tabular}{lllll}
\hline Treatments & $\begin{array}{l}\text { Mean population of } \\
\text { legume flower thrips }\end{array}$ & $\begin{array}{l}\text { Mean population of } \\
\text { legume pod borer }\end{array}$ & $\begin{array}{l}\text { Percentage (\%) reduction of population } \\
\text { of flower thrips compared to control }\end{array}$ & $\begin{array}{l}\text { Percentage (\%) reduction of population } \\
\text { of pod borer compared to control }\end{array}$ \\
\hline Annona muricata & $10.90 \mathrm{c}$ & $2.09 \mathrm{e}$ & 69.28 & 78.52 \\
Azadirachta indica & $15.80 \mathrm{bc}$ & $4.42 \mathrm{c}$ & 55.48 & 57.78 \\
Piper guineense & $14.30 \mathrm{c}$ & $2.80 \mathrm{de}$ & 59.70 & 73.26 \\
Jatropha curcas & $17.01 \mathrm{bc}$ & $4.28 \mathrm{~cd}$ & 52.07 & 59.12 \\
Lambdacyhalothrin & $22.36 \mathrm{~b}$ & $6.63 \mathrm{~b}$ & 37.00 & 36.68 \\
Control & $35.49 \mathrm{a}$ & $10.47 \mathrm{a}$ & 100 & 100
\end{tabular}

Means values followed by the same letter within the column are not significantly different by DMRT

muricata and $P$. guineense in reducing the cowpea pod damage was significantly $(p>0.05)$ higher than all the extracts and lambdacyhalothrin. All the extracts significantly $(p>0.01)$ reduced the cowpea pod damage compared with untreated control.

\section{Effect of treatments on the dry weights of cowpea pod} The effect of the treatments on cowpea yield is shown in Fig. 4.

The number of pods produced per plant was significantly greater $(p<0.05)$ in plots sprayed with A. muricata, followed by $P$. guineense with mean values of 173.8 $\mathrm{g}$ and $168.2 \mathrm{~g}$, respectively. Plots treated by these two extracts also gave higher grain yields than those of $A$. indica and J. curcas. The untreated check gave the lowest yield during the study, although the plots treated with synthetic insecticide (lambdacyhalothrin) recorded lower pod yield than the extracts used.

\section{Discussion}

The results of this study have ascertained the potential of the four plant extracts tested in controlling $M$. vitrata and M. sjostedti on cowpea plants. A. muricata proved higher efficacy over other extracts against $M$. vitrata and M. sjostedti indicating its high potential as biopesticides. This finding is in line with Lala et al. (2014) who reported that the aqueous and oil extracts of Annona squamosa and Annona muricata were effective against Aedes albopictus and Culex quinquefasciatus at varying levels of application. Riser (1996) also confirmed the efficacy of Annona muricata plant extracts for the control of field insect pests of cowpea .Similarly, Jaramilloa, Arangoa, and Gonzalezb (2000) reported that A. muricata exhibited significant antifeedant, pesticidal, anticancerous, anti-tumorous, and anti-viral properties in their studies. Ishuwa, N. Elkanah, and Wahedi (2016) also reported that $A$. muricata was very effective against Callosobruchus maculatus on stored cowpea.

The efficacy of Annona muricata extract was higher than lambdacyhalothrin for the protecting cowpea against M. vitrata and M. sjostedti in this study. This result supports the findings of Padma, Pramod, Thyogarajan, and Khosa (1998) who stated that Annona muricata-based products were more effective than synthetic insecticides in the control of different order of insect pests. The bioactivity of Annona muricata has been attributed to various

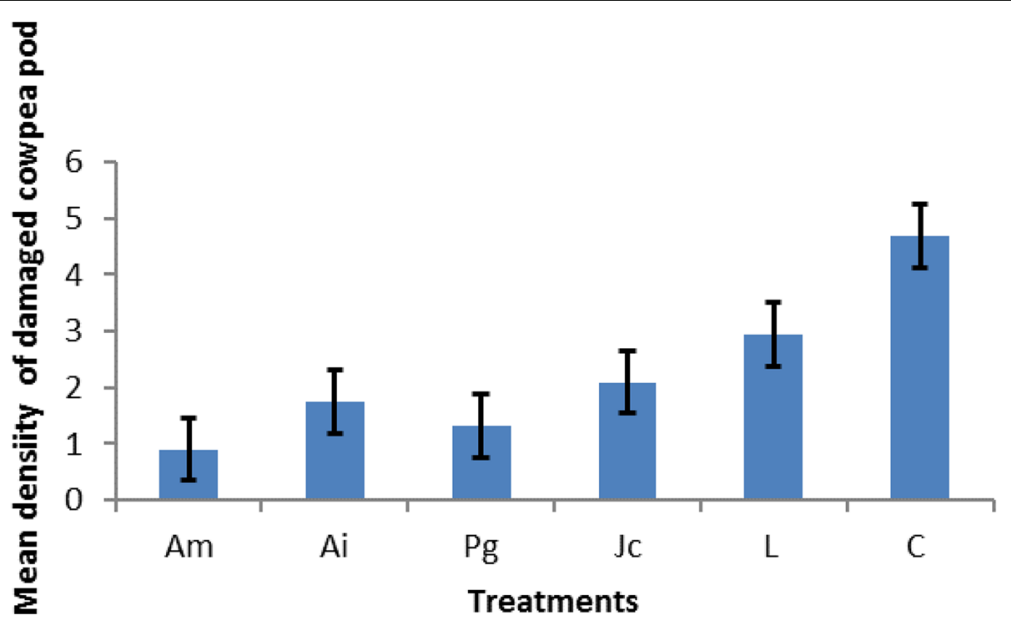

Fig. 3 Effect of treatments on the number of damaged cowpea pod. Mean values are the number damage cowpea pod observed from different plots treated with different botanicals. Am, plot treated with Annona muricata; Ai, plot treated with Azadirachta indica; Pg, plot treated with Piper guineense; Jc, plot treated with Jatropha curcas; L, lambdacyhalothrin; C, control (no treatment) 


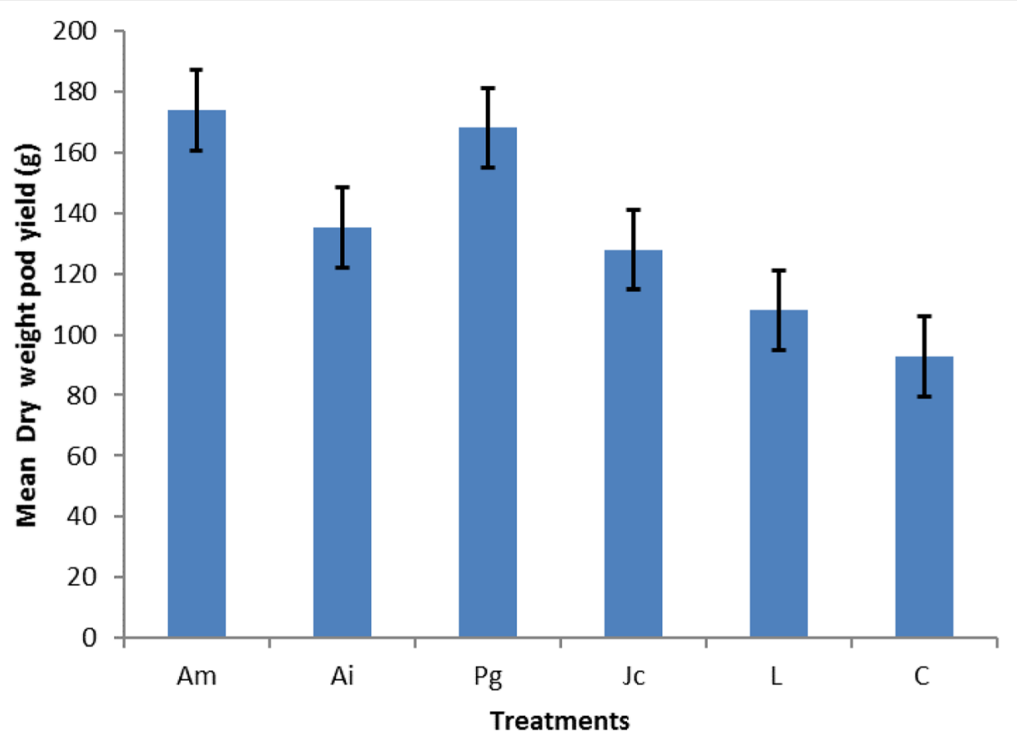

Fig. 4 Effect of treatments on the dry weights (gram) of cowpea pod. Mean values are the dry weight of cowpea pod harvested from different plots treated with different botanicals. Am, plot treated with Annona muricata; Ai, plot treated with Azadirachta indica; Pg, plot treated with Piper guineense; Jc, plot treated with Jatropha curcas; L, lambdacyhalothrin; C, control (no treatment)

chemical compounds which include Annonaceous acetogins, muri-catenol, annomuricatin, javoricin, montanacin, montecristin, coronin, and donhexocin numbering over 50 which prevents development of insect pests (Jaramilloa et al., 2000). According to Lala et al. (2014), extracts of A. muricata and A. squamosa contain alkaloids and flavonoids compounds that perhaps confer their biological insecticidal proprieties.

The efficacy of $P$. guineense was very close to $A$. muricata against $M$. vitrata and $M$. sjostedti showing no significant difference between the two. This corroborate the finding by Oparaeke, M. Dike, and Amatobi (2005) who informed that direct spraying of $P$. guineense extracts against Clavigralla tomentosicollis and Maruca larvae on cowpea plants caused illusion on them at first and followed by killing them within 10-15 min of contact with the extracts. Several past workers have reported the efficacy of $P$. guineense extracts on stored insect pests. Idoko and Adesina (2012) conveyed that sole plant powders application of $P$. guineense caused adults mortality, suppressed oviposition by female beetles on cowpea grains, and F1 progeny emergence of Callosobruchus maculatus. Fasaki and Aberejo (2002) also reported that pulverized plant material from $P$. guineense inhibited egg hatchability and adult emergence of Dermestes maculatus Degeer in smoked catfish (Clarias gariepinus) during storage. A similar report was given by Golob, Moss, Males, Fidgen, and Evans (1999) that P. guineense powder, oil and hexane, and acetone extracts are effective in causing mortality and reducing oviposition of various insects when applied to cowpea and maize crops.

A. indica was also found very effective in reducing legume pod borer and legume flower thrips infestation in this study. This finding is also in line with several reports on the insecticidal properties of $A$. indica. Ivbijaro and Bolaji (1990) reported that $A$. indica-based products were more effective than synthetic insecticides for the control of aphids and white flies. Schmutterer (1995) established the potential of products from A. indica for the control of field insect pests of eggplant and okra. Adedire and Lajide (2000) reported that A. indica plant has developed highly intricate chemical fortifications against insect attack, and they have therefore provided a rich source of biologically active chemical compounds which are highly potent in protecting crops against pests. According to Ascher (1993), A. indica (neem) derivatives provide broad spectrum control of over 200 species of phytophagous insects. Ojo and Ugwu (2012) also reported that ethanol seed extracts of $A$. indica were very effective in controlling insect pests of Adansonia digitata L. (Baobab) seedlings.

Jatropha curcas was also found effective in reducing the infestation of legume pod borer and flower thrips population in this study. This supports the earlier report on the insecticidal properties of J. curcas. Salimond and Abdullah (2008) reported Jatropha curcas possess insecticide or antifeedant properties that affect various insects families. Ugwu, Umeh, and Omoloye (2017) reported that J. curcas seed extracts proved effective in reducing the population of $M$. vitrata on cowpea under rain fed condition. Several authors reported the insecticidal properties of J. curcas extracts against stored insect pest. Sabbour and Abd-ElRaheem (2013) informed that Jatropha curcas oil deterred oviposition and adversely influence fecundity of Callosobruchus maculatus (F.) and Callosobruchus chinensis (L.). 
Similarly Habou et al. (2014) reported that J. curcas seeds' oil was toxic to the adults of $C$. maculatus and Bruchidius atrolineatus and reduced adult survival and oviposition by 85 to $90 \%$ in the females of both species.

The plant extracts evaluated in this study were observed to be more effective than lambdacyhalothrin (synthetic chemical) in this study. This confirmed the report of Basedow, Obiewatsch, Bernal Vega, Kollmann, and Nicol (2002) which stated that $A$. indica-based products were more effective than synthetic insecticides for the control of aphids and white flies. Similarly, Ojo and Ugwu (2012) reported that $A$. indica seed extracts were more effective than synthetic insecticides in controlling the insect pests of Adansonia digitata seedling in the field.

\section{Conclusion}

Extracts from A. muricata, $P$.guineense, A. indica, and $J$. curcas were found to be effective in controlling legume pod borer and flower thrips on cowpea. However, $A$. muricata and P. guineense extracts were more effective than other extracts and lambdacyhalothrin for the control of M. vitrata and M. sjostedti. All the extracts significantly reduced legume pod borer and flower thrips infestation and enhanced cowpea yield compared to untreated control. These extracts at $10 \mathrm{ml} / 1 \mathrm{l}$ were more efficacious than lambdacyhalothrin at $5 \mathrm{ml} / 10 \mathrm{l}$ in controlling legume pod borer and flower thrips on cowpea. These plants are widely available, cheap, and easy to extract in crude forms; consequently, farmers should adopt their uses for the management of insect pests in order to curtail human and environmental hazards associated with the use of synthetic insecticides and to reduce cost of purchase.

\section{Abbreviations \\ FAO: Food and Agricultural Organization; FAOSTAT: The Food and Agriculture Organization Corporate Statistical Database; FRIN: Forestry Research Institute of Nigeria; GMT: Greenwich meridian time; IAR\&T: Institute of Agricultural Research and Training; WAS: Weeks after sowing}

\section{Acknowledgements}

The author is grateful to the field assistants who helped in maintaining the field during the research activities and to Miss Onadeko Rachael Abidemi for her assistance in the data collection.

\section{Author's contribution}

Ugwu Juliana Amaka conceptualized and designed the work; collected, analyzed, and interpreted the data; and drafted and edited the manuscript. The author read and approved the final manuscript.

\section{Funding}

This research did not receive any specific grant from funding agencies in the public, commercial, or not-for-profit sectors.

\section{Availability of data and materials}

Not applicable.

\section{Competing interest}

The author declares no competing interests.
Ethics approval and consent to participate

Not applicable.

\section{Consent for publication}

Not applicable.

Received: 14 November 2019 Accepted: 19 March 2020

Published online: 07 April 2020

\section{References}

Adaji, M. J., Olufala, O. O. \&, Aliyu, L. (2007). Effect of intra-row spacing and stand density on the growth and yield of cowpea (Vigna unguculata (L.) Walp). In: Olulaja, O. O., Omokore, D.F., Akpa G. N. and Sanni, S. A. (eds.). Proceedings of the 41st Annual Conference of the Agricultural Society of Nigeria (ASN) held at the Institute for Agricultural Research, Samaru, Ahmadu Bello University, Zaria between 22nd and 26th October, 2007. pp 153-157.

Adedire, C.O. \& Lajide, L. (2000). Effect of pulverized plant materials on fish damage and growth performance of the fish beetle Dermestes maculatus (Degeer). Book chapter; Conference paper : Entomology in nation building: the Nigerian experience. The Proceedings of ESN 30th Annual Conference held at Kano, Nigeria, 4th-7th October 19992000 pp. 215-218 ref.16 cabdirect.org

Akbar, M.F., Haq, M.A., Parveen, F., Yasmin, N., \& Sayeed, S.A. (2010). Determination of synthetic and bio-insecticides residues during aphid, Myzus persicae (Sulzer) control on cabbage crop through high performance liquid chromatography Source:Pakistan Entomologist [1017-1827] [Peer Reviewed] Akbar, MF Year: 2010 Issue / Part: 32 no: 2 sec: 155

Alghali, A.M., (1992). Insecticide application schedules to reduce grain yield losses caused by insect pests of cowpea in Nigeria.. Int. J Trop Insect Sci.13: 725. https://doi.org/10.1017/S1742758400007967

Amatobi, C.I (1995).Insecticide application for economic production of cowpea grains in the northern Sudan savanna of Nigeria. Int J Pest Manag 41:14-18. Google scholar citation- cross ref.

Anyaele, O.O., Amusan, A.A.S., Okorie, T.G. \& Oke, O.A. (2002). Toxicity of hexanolic extracts of Piper guineense Schum \& Thonn. (Piperaceae) seed oil to larvae of Aedes aegypti (L.) Nig. J. Ent., 19: 15-21 -Google scholar citation- cross ref.

Ascher, K.R. S. (1993). Nonconventional insecticidal effects of pesticides available from the neem tree, Azadirachta indica Archives of Insect Biochemistry and Physiology 22:433-449 (1 993)

Basedow, T; Obiewatsch, H.R; Bernal Vega, J.A., Kollmann, S. \& Nicol C.M.Y. (2002). Control of aphids and whiteflies (Homoptera; Aphididae and Aleyrodidae) with different neem preparations in laboratory, greenhouse and field: effects and limitations / die Bekämpfung Von Blattläusen Und Weißen Fliegen (Homoptera: Aphididae Und Aleyrodidae) Mit Verschiedenen NeemPräparaten in Labor, Gewächshaus Und Freiland: Wirkungen Und Grenzen." Zeitschrift Für Pflanzenkrankheiten Und Pflanzenschutz / Journal of Plant Diseases and Protection 109, no. 6 (2002): 612-23. www.jstor.org/ stable/43215484

Dreyer, H., Baumgartner, J., \& Tamo, M. (1994). Seed damaging field pests of cowpea (Vigna unguiculata) (Walp) in Benin: occurrence and pest status. Int. J. Trop. Pest Manage, 40, 252-260.

Edema, R., \& Adipala, E. (1996). Effect of crop protection management practice on yield of seven cowpea varieties in Uganda. Int. J. Pest Manage., 42, 317-320.

Ekesi, S., Maniania, N. K., Onu, I., \& Löhr, B. (1998). Pathogenicity of entomopathogenic fungi (Hyphomycetes) to the legume flower thrips, Megalurothrips Sjostedti (Trybom) (Thysan., Thripidae). Journal of Applied Entomology, 122(1-5), 629-634 https://doi.org/10.1111/j.1439-0418.1998. tb01557.x.

FAO (2002). World agriculture: towards 2015/2030. Summary report, Rome.

FAOSTAT 2014. Country Statistics FAO website Last visited June 11, 2016: http:// www.fao.org/economic/ess/countrystat/countrystathome/country-statistics/ en/

FAOSTAT/FAO. 2011. Production - crops - world list. 2009. FAO, Rome, Italy. http://faostat.fao.org/site/567/D

Fasaki, E. A., \& Aberejo, B. A. (2002). Effect of some pulverized plant materials on the developmental stages of fish beetle, Dermestes maculatus Degeerin smoked catfish (clarias gariepinus) during storage. Bioresource Technology, 85, 173-177.

FRIN (2014). Forestry Research Institute of Nigeria Annual Bulletin, Ibadan Nigeria. $64 \mathrm{pp}$. 
Golob, P., Moss, C., Males, M., Fidgen, A., \& Evans, J. (1999). The use of spices and medicinals as bioactive protectants for grains, (p. 239). Rome: FAO.

Grigolli, J., Lourenção, A., \& Avila, C. (2015). Field efficacy of chemical pesticides against Maruca vitrata Fabricius (Lepidoptera: Crambidae) infesting soybean in Brazil. American Journal of Plant Sciences, 6, 537-544 https:/doi.org/10.4236/ajps.2015.64058.

Habou, Z., Haougui, A., Basso, A., Toudou, A., Haubruge, E., \& Verheggen, F. (2014). Insecticidal effect of Jatropha curcas L. seed oil on Callosobruchus maculatus Fab and Bruchidius atrolineatus Pic (Coleoptera: Bruchidae) on stored cowpea seeds (Vigna unguiculata L. Walp.) in Niger. African Journal of Agricultural Research, 9, 2506-2510. https://doi.org/10.5897/AJAR2013.7578.

Idoko, J. E., \& Adesina, J. M. (2012). Evaluation of the powder of Piper guineense and pirimiphos-Methly F for the control of cowpea beetle Callosobruchus maculatus (F.). Journal of Agricultural Technology, 8(4), 1365-1374.

Ishuwa, M. N. Elkanah, O. S. \& Wahedi J. A. (2016), Grain protectant potential of Annona muricata and A. senegalensis against cowpea seed Bruchid Callosobruchus maculatus Fab. (Coleoptera: Bruchida). Asian Research Journal of Agriculture 1(1): 1-7, 2016

Ivbijaro, M. F. (1983). Preservation of cowpea, Vigna unguiculata (L.) Walp, with the neem seed, Azadirachta indica A. Juss. Protection Ecology.5: 177 -182 Google scholar-agris.fao.org

Ivbijaro, M. F., \& Bolaji, O. O. (1990). Effects of cypermethrin+ dimethoate and extracts of Piper guineense and Azadirachta indica on the pests and yield of cowpea, Vigna unguiculata. The Journal of Agricultural Science, 115(2), 227-231. Google scholar-cambridge.org

Jackai, L.EN., Singh, S.R., Raheja, A.K \& Wiedijk, K. (1985). Recent trends in the control of cowpea pests in Africa. In Cowpea research, production and utilization. Singh, S.R. and Rachie, K.O (Eds), 233 - 243. Chickester, John Willey and Sons. UK.

Jaramilloa, M. C., Arangoa, G. J., \& Gonzalezb, M. C. (2000). Cytotoxicity and antileishmanial activity of Annona muricata pericarp. Pitoterapia, 2000(71), 183-186.

Karungi, J., Adipala, E., Nampala, P., Ogenga-Latigo, M. W., \& Kyamanywa, S. (2000). Pest management in cowpea. Part 3.Quantifying the effect of cowpea field pests on grain yields in eastern Uganda. Crop Protection, 19, 343-347.

Lala, H R R., Herisolo, A. R., Fara, N.R., Beby, R., Pierre, H. R. \&Patrick, M.(2014). Efficacy of seed extracts of Annona squamosa and Annona muricata (Annonaceae) for the control of Aedes albopictus and Culex quinquefasciatus (Culicidae). Asian Pacific Journal of Tropical Biomedicine 2014; 4(10): 798-806

Logan, J. W. M., Cowie, R. H., \& Wood, T. G. (1990). Termite (Isoptera) control in agriculture and forestry by non-chemical methods: a review. Bulletin of Entomological Research, 80, 309-330.

Malgwi, A. M. \& Onu, J. I (2004) Insect pest of cowpea and groundnut in Gire Local Government Area, Adamawa State. Nigeria Journal of Entomology 21: 137-151 Google scholar citations NJ Entomol, 2004- cross. ref.

Musa, A.K., Dike, M.C., Amatobi, C.I., \& Onu I. (2007). Evaluation of methanolic extracts of selected indigenous plant materials in suppressing Trogoderma granarium Everts (Coleoptera: Dermestidae) infestation on stored groundnuts. J. Agric. Res. Policies, 2(3): 91-95.Musa, A.K.-Google scholar citations-cross ref.

Ofuya, T., Okoye, B., \& Olola, A. (1992). Efficacy of a crude extract from seeds of Monodora myristica (Gaertn.) Dunal as surface protectant against Callosobruchus maculatus (F.) attacking legume seeds in storage / Wirksamkeit eines Rohextraktes aus Samen von Monodora myristica (Gaertn.) Dunal als Oberflächenschutzmittel gegen Callosobruchus maculatus (F.), der Leguminosensamen im Lager schädigt. Zeitschrift Für Pflanzenkrankheiten Und Pflanzenschutz / J. Plant Dis. Protection, 99(5), 528-532. Retrieved March 24, 2020, from www.jstor.org/stable/43386100. https:/doi.org/10.1186/ s41936-020-00153-3.

Ojo, O. M \& Ugwu, J.A. (2012). Comparative effects of Azadirachta indica A. Juss (neem) seed extract and cypermethrin on insect pests of Adansonia. digitata L. (Baobab) seedlings in Ibadan Southwest Nigeria. African Journal of Agricultural Research and Development, Volume 5, Number1,.Pp 99-103. 2012. Google scholar citation-search.-proquest.com-cross ref.

Oparaeke, A. M. Dike, M. C. \& Amatobi C. I. (2005). Evaluation of botanical mixtures for insect pests management on cowpea plants Journal of Agriculture and Rural Development in the Tropics and Subtropics 106, No.1, 2005, pages 41-48 AM,Oparaekr-Google scholar DOAJ Directory of Open Access Journals

Oparaeke, A. M. (2006). Bioefficacy of plant extract mixtures for the protection of cowpea flowers against Megalurothrips sjostedti Trybom (Thripidae). Journal of Plant Sciences, 1: 1-7 Google scholar available at Free E-Journals

Oparaeke, A.M., Dike, M.C. \& Onu, I. (1998). Evaluation of seed and leaf powders of neem, Azadirachta indica A. Juss and pirimiphos-methyl for control of Callosobruchus maculatus F. in stored cowpea. ESN Occasional Publi., 3: 237242. AM,Oparaekr-Google scholar
Owolabi, A.O., Ndidi, U.S., James, B.D. \& Amune, FA. (2012). Proximate, antinutrient and mineral composition of five varieties (improved and local) of cowpea, Vigna unguiculata, commonly consumed in Samaru community, Zaria-Nigeria Asian Journal of Food Science and Technology 4(2):70-72. Google scholar citation- academia.edu

Padma, P., Pramod, N.P., Thyogarajan, S.P. \& Khosa R.L. (1998). Effect of the extract of Annona muricata and Petunia nyctaginiflora on Herpes simplex virus Journal of Ethnopharmacology, 61 (1998), pp. 81-83- Google scholar- journalarticle.ukm.my

Riser, M.J. (1996); Five novel mono-tetrahydrofuran ring acetogenins from the leaves of Annona muricata. J.Nat.Prod. 1996.59(2);100-108

Rusoke, D. G., \& Rubaihayo, P. R. (1994). The influence of some crop protection management practices on yield stability of cowpeas. African Crop Science Journal, 2, 43-48 https://doi.org/10.4314/acsj.v2i1.54673.

Sabbour, M.M. \& Abd-El-Raheem M.A. (2013). Repellent effects of Jatropha curcas, canola and Jojoba seed oil, against Callosobruchus maculatus (F.) and Callosobruchus chinensis (L.). Journal of Applied Sciences Research, 9(8): 4678-4682, 2013 ISSN 1819-544X

Salimond, J.A. \& Abdullah, R.A. (2008). Physiochemical properties of Malaysian Jatropha curcas seed oil, Sains Malaysian, 37; 379-382. Google scholar citation- journalarticle.ukm.my

Saxena, R.C. (1989). Insecticides from neem. In: Insecticide of Plant Origin, Arnason J.T., B.J.R. Philogene and P. Morand (Eds.). American Chemistry Society, Washington, DC., pp:110-135.

Schmuttere, H. (1990). Properties and potential of natural pesticides from the neem tree, Azadirachta indica. Annual Review of Entomology, 35, 271-297.

Schmutterer, H. (1995). The neem tree. Source of unique natural products for integrated pest management, medicine, industry and other purposes. Weinheim, New York, Basel, Cambridge

Singh, S.R. \& Allen D.J. (1980). Pests, diseases, resistance and protection of (Vigna unguiculata (L.) Walp. In: Summerfield, R.J., Bunting, A.H.K. (Eds.), Advances in Legume Science, Royal Botanic Gardens, London, and Ministry of Agriculture, Fish and Food, MAFF, pp. 419-443.

Singh, S. R., \& Van Emden, H. F. (1979). Insect pests of grain legumes. Annual Review of Entomology, 24, 255-278.

Soomro, A. M., Seehar, G. M., Bhangar, M.I. \& Channa N.A. (2008). Pesticides in the blood samples of spray-workers at agriculture environment: The toxicological evaluation. Pakistan Journal of Analytical \& Environmental Chemistry, 9(1), 6. Google scholar- pjaec.pk

Sowunmi, O. \& Akinnusi, O.A. (1983). Studies on the use of neem kernel in the control of stored cowpea beetle, Callosobruchus maculatus (F.). Tropical grain legume bulletin,.. Google scholar- agris.fao.org

Tamò, M., Baumgärtner, J., \& Gutierrez, A. P. (1993). Analysis of the cowpea agroecosystem in West Africa. II. Modelling the interactions between cowpea and the bean flower thrips Megalurothripssjostedti (Trybom) (Thysanoptera, Thripidae). Ecological Modelling, 70(1-2), 89-113. https://doi.org/10.1016/ 0304-3800(93)90074-3.

Tamo, M., Bottenberg, H. Arodekoum, D.\& Adeoti R. (1997). The feasibility of classic biological control of two major cowpea insects. In. Singh, B.B., Mohan Ray D.R., Dashiell, K.E. and Jackai, L.E.N (Eds). Advances in cowpea research. co publication of International Institute of Agricultural and Japan International Center for Agricultural Sciences. Nigeria pp 259-270.

Tanzubil, P. B. (1991). Control of some insect pests of cowpea (Vigna unguiculuta) with neem (Azadirachta indica A Juss.) in Northern Ghana. Trop. Pest Manage, 37, 216-217.

Tanzubil, P. B. (2000). Field evaluation of neem (Azadirachta indica) extracts for control of insect pests of cowpea in Northern Ghana. Journal of Tropical Forest Products, 6(2), 165-172. Google scholar-cabdirect.org

Ugwu, J.A (2016). Laboratory bioassay of selected plant extracts for the management of Cowpea weevil Callosobruchus maculatus (F.) (Coleoptera: Bruchidae) MAYFEB Journal of Agricultural Science. ISSN2371-512X Vol ( 3) 2016. 21-29

Ugwu J.A, Omoloye A.A and Obasaju F.T.(2012). Potentials of Azadirachta indica (A.Juss) and Cymbopogon citratus (Staph) powder for the control of Oryzaephilus mercator (Fauvel) on Invingia wombolu kernel. Journal of Sustainable Environmental Management Vol. 4.pp 75-80. Google scholar citation. mayfeb.com- cross ref

Ugwu, J. A., Umeh, V. C., \& Omoloye, A. A. (2017). Field evaluation of extracts of four selected plants for the management of maruca vitrata fab on cowpea vigna unguiculata L. walp. International Journal of Food Safety, Nutrition, Public Health and Technology, 9(7), 60-65 Retrieved from https://search. proquest.com/docview/1953850706?accountid=1136.

\section{Publisher's Note}

Springer Nature remains neutral with regard to jurisdictional claims in published maps and institutional affiliations. 